\title{
Response from Drs. Formica/Zaniboni to Dr. Milano
}

\author{
V. Formica ${ }^{2} \cdot$ A. Zaniboni ${ }^{1}$
}

Received: 7 June 2016 / Accepted: 7 June 2016 / Published online: 17 June 2016

(C) Springer-Verlag Berlin Heidelberg 2016

We would like to thank Dr. Milano et al. for the point they made on the possible role of drug-induced immune response occurring during treatment with either anti-VEGF or anti-EGFR agents [1].

We acknowledge the increasing importance that immune checkpoint inhibitors are gaining in the therapeutic armamentarium in oncology [2].

However, the impact of antitumor immunity, and in particular of PD-1/PD-L1-modulated immune response, is far to be fully elucidated in colorectal cancer.

Initial clinical data demonstrated no response with anti-PD-1 or anti-PD-L1 drugs in colorectal cancer [3, 4]. Subsequently, the clinical 'niche' (5-10\%) of microsatellite instable tumors was suggested to be sensitive to PD-1/ PD-L1 targeting agents for this disease [5].

Moreover, the different biologic drugs in use for CRC patients may have different power in triggering an immune reaction, such as the NK-related antibody-dependent cellular cytotoxicity (ADCC), which is higher for the $\operatorname{IgG} 2$ cetuximab and lower for the IgG1 panitumumab, and this should be further taken into consideration [6].

We do strongly agree that combination regimens of antiVEGF or anti-EGFR therapies with immunotherapies represent an extremely attractive new frontier; however, the molecular basis of such a treatment approach still needs to be accurately defined.

A. Zaniboni

zanib@numerica.it; alberto.zaniboni@poliambulanza.it

1 Medical Oncology Department, Fondazione Poliambulanza, Via Bissolati 57, 25124 Brescia, Italy

2 Medical Oncology Unit, Tor Vergata University Hospital, Rome, Italy

\section{References}

1. Milano G (2016) Anti-VEGF and anti-EGFR agents open up new horizons changing the landscape for their associations. Cancer Chemother Pharmacol. doi:10.1007/s00280-016-3081-z

2. Zou W, Wolchok JD, Chen L (2016) PD-L1 (B7-H1) and PD-1 pathway blockade for cancer therapy: mechanisms, response biomarkers, and combinations. Sci Transl Med 8(328):328rv4. doi:10.1126/scitranslmed.aad7118 (review)

3. Brahmer JR, Tykodi SS, Chow LQ, Hwu WJ, Topalian SL, Hwu P, Drake CG, Camacho LH, Kauh J, Odunsi K, Pitot HC, Hamid O, Bhatia S, Martins R, Eaton K, Chen S, Salay TM, Alaparthy S, Grosso JF, Korman AJ, Parker SM, Agrawal S, Goldberg SM, Pardoll DM, Gupta A, Wigginton JM (2012) Safety and activity of anti-PD-L1 antibody in patients with advanced cancer. N Engl J Med 366(26):2455-2465. doi:10.1056/NEJMoa1200694

4. Topalian SL, Hodi FS, Brahmer JR, Gettinger SN, Smith DC, McDermott DF, Powderly JD, Carvajal RD, Sosman JA, Atkins MB, Leming PD, Spigel DR, Antonia SJ, Horn L, Drake CG, Pardoll DM, Chen L, Sharfman WH, Anders RA, Taube JM, McMiller TL, Xu H, Korman AJ, Jure-Kunkel M, Agrawal S, McDonald D, Kollia GD, Gupta A, Wigginton JM, Sznol M (2012) Safety, activity, and immune correlates of anti-PD-1 antibody in cancer. N Engl J Med 366(26):2443-2454. doi:10.1056/ NEJMoa1200690

5. Le DT, Uram JN, Wang H, Bartlett BR, Kemberling H, Eyring AD, Skora AD, Luber BS, Azad NS, Laheru D, Biedrzycki B, Donehower RC, Zaheer A, Fisher GA, Crocenzi TS, Lee JJ, Duffy SM, Goldberg RM, de la Chapelle A, Koshiji M, Bhaijee F, Huebner T, Hruban RH, Wood LD, Cuka N, Pardoll DM, Papadopoulos N, Kinzler KW, Zhou S, Cornish TC, Taube JM, Anders RA, Eshleman JR, Vogelstein B, Diaz LA Jr (2015) PD-1 blockade in tumors with mismatch-repair deficiency. N Engl J Med 372(26):2509-2520. doi:10.1056/NEJMoa1500596

6. Monteverde M, Milano G, Strola G, Maffi M, Lattanzio L, Vivenza D, Tonissi F, Merlano M, Lo Nigro C (2015) The relevance of ADCC for EGFR targeting: a review of the literature and a clinically-applicable method of assessment in patients. Crit Rev Oncol Hematol 95(2):179-190. doi:10.1016/j.critrevonc.2015.02.014 (review) 